\title{
«Ciało» na wojnie. \\ Wokół Soli ziemi Józefa Wittlina
}

\section{A body at war. On Józef Wittlin's Sól ziemi}

\author{
Beata Koper \\ Uniwersytet im. Adama Mickiewicza
}

\begin{abstract}
The article introduces methodology of cultural studies depicting the soldier's body in Józef Wittlin's novel Sól ziemi (The Salt of the Earth). Texts about the novel and articles from other scientific disciplines (for example history, philosophy, medicine) allow to draw a wide context of interpretation. They show that changes in the perception of a body depend on scientific progress and industrialization. World War I allows Wittlin to reveal the ambiguous progress of medical science which can cure crippled bodies, but at the same time it requires the very same war to evolve. The literary reflection and discourses of natural and social sciences help us to understand changes that happened in Europe in the 20th century and to notice their present repercussions.
\end{abstract}

Key words: body, cultural studies, World War I, medicine, industrialization

Streszczenie: Artykuł przybliża metodologię badań kulturowych na przykładzie analizy obrazowania ciała żołnierza w powieści Józefa Wittlina Sól ziemi. Teksty wokół powieści oraz artykuły z innych dyscyplin (historia, filozofia, medycyna) pozwalają nakreślić szeroki kontekst interpretacyjny. Pokazują, że zmiany w postrzeganiu ciała wiążą się z postępem nauki i industrializacją. Odczytanie powieści z perspektywy badań kulturowych pozwala ujawnić niejednoznaczność postępu nauk medycznych, które potrafią naprawiać okaleczone ciała żołnierzy, jednocześnie przyczyniając się do rozwoju okrutnych metod walk. Refleksja literacka razem z dyskursami nauk przyrodniczych i społecznych pozwala zrozumieć przemiany, jakie dokonały się w Europie w XX wieku, i dostrzec ich skutki we współczesności.

Słowa kluczowe: ciało, badania kulturowe, I wojna światowa, medycyna, industrializacja

Obraz człowieka dotkniętego wojną pojawia się w kulturze nieustannie, tworzy klisze przynależne XX wiekowi. Rekrut z I wojny światowej chroni się w okopach; ciało zniszczone, zdegradowane, odziane w pasiak stało się symbolem obozów; ciężko doświadczony weteran wojenny pojawia się 
jako nieodłączny element narracji o wojnie w Wietnamie. Wyjątkowość tych poszczególnych wydarzeń zostaje zakwestionowana, ich źródła można odnaleźć znacznie wcześniej niż początkowo zakładano. Korzeni nazizmu można dopatrzeć się w polityce imperialnej Europy, a wśród pierwszych ludobójstw XX wieku wymienia się stłumienie powstania afrykańskich ludów Herero i Namaqua przez wojska Cesarstwa Niemieckiego (1904-1907) oraz rzeź Ormian (1915-1917). W tak szeroko zakreślonej perspektywie, obejmującej wszystkie konflikty minionego wieku oraz dzieje działań militarnych i politycznych państw zachodniej Europy w epoce nowożytnej, postrzeganie ciała w okresie I wojny światowej wydaje się zaledwie jednym z elementów w łańcuchu historii. Podważenie statusu wyjątkowości nie ma na celu pokazania cech wspólnych i zniwelowania jednostkowości poszczególnych wydarzeń. Wręcz przeciwnie, pozwala spojrzeć na ciało naznaczone wojną w szerokiej perspektywie i podkreślić te zjawiska i wydarzenia, które wyewoluowały pod wpływem ówczesnych przemian społecznych, a które wcześniej nie występowały lub nie pojawiały się w dużej skali. Taki punkt widzenia umożliwiają metodologie badań kulturowych. O zwrotach w humanistyce mówi się nieustannie, być może nadużywając niekiedy tego sformułowania. W przypadku tematyki cielesności również można mówić o zmianie paradygmatu lub, mówiąc ostrożniej, o nowej perspektywie.

Podstawowe informacje na temat antropologii ciała przedstawia Beata Przymuszała w 1. numerze „Polonistyki. Innowacji” z 2015 roku (Przymuszała, 2015). Dwa utwory poetyckie (Szkic do erotyku współczesnego Tadeusza Różewicza i laboratur widal pedigri pro wi Marcina Barana), przywołane przez autorkę, stają się przyczynkiem do refleksji nad ciałem w kulturze współczesnej. W tym samym numerze Wiesława Wantuch proponuje lekturę Piosenki o porcelanie Czesława Miłosza oraz Końca i poczatku Wisławy Szymborskiej, by zmierzyć się z tematyką wojenną na lekcji języka polskiego (Wantuch, 2015). W obu przypadkach, oprócz namysłu nad trudnymi problemami, pojawiają się również zagadnienia literaturoznawcze, propozycje narzędzi umożliwiających interpretację współczesnych utworów. Zaproponowana przeze mnie lektura Soli ziemi Józefa Wittlina wpisuje się w oba porządki myślenia o analizie dzieła literackiego. Wychodzi od metodologicznego zwrotu i może stanowić zarówno rozwinięcie zaproponowanych ujęć (metodologicznego i tematycznego), jak i wstęp do obu tematów. $\mathrm{W}$ tym drugim przypadku nie bez znaczenia pozostanie chronologia powstania poszczególnych utworów.

$* * *$

Na współczesną konceptualizację ciała w obliczu Wielkiej Wojny, oprócz sztuki masowej, wpływają między innymi teksty naukowe, historyczne kompendia, literatura. Wszystkie narracje czerpią z pamiętników, zapisków i dokumentów z tamtego okresu. Wśród literackich narracji ważnym dziełem pozostaje Sól ziemi Józefa Wittlina, powieść tworzona przez 10 lat, wydana po raz pierwszy w 1935 roku. Nie bez znaczenia wydaje się dystans 
czasowy pomiędzy opisywanym wydarzeniem a datą ukończenia powieści. Hanna Trubicka podkreśla, iż właśnie ten brak bezpośredniego zapisu wrażeń (który widoczny jest w Hymnach z 1920 roku) powoduje, że skłonni jesteśmy odczytywać Sól ziemi w kontekście kryzysu gospodarczego lat 30. i krytyki modelu kultury europejskiej (Trubicka 2011, 210). Powieść należałoby zatem odczytać nie jako zapis doświadczenia autora, ale jako refleksję, która bez owego doświadczenia nie mogłaby powstać. Wittlin w sposób mistrzowski pokazuje kondycję człowieka-żołnierza, „mięsa armatniego”, jednostki w obliczu milionowego tłumu zaangażowanego w machinę wojenną. Zderzenie tekstu literackiego z narracją naukową, w moim odczuciu, pozwala dostrzec konstytutywne elementy dyskursu, rozumianego zarówno jako poszczególne dziedziny wiedzy jak i rywalizację praktyk złożonych ze zdarzeń dyskursywnych (por. Foucault 1977; 2002), oddziałujące na naszą wyobraźnię, a co za tym idzie - konceptualizację ciała.

\section{Przymierze Marsa z Eskulapem}

W owych dniach zapalczywy i bezmyślny Mars, który czasu pokoju nie ukrywał swej pogardy dla Eskulapa, nagle zaczął traktować go serio. Przymilnie mu się łasząc, otwarcie już zabiegał o jego względy. Albowiem bez zgody Eskulapa nie mógł rozporządzać ciałem żadnego mężczyzny. Jakoż o losach wojny decydowali przede wszystkim - lekarze (Wittlin 1991, 68).

Bohaterem powieści Wittlina jest przeciętny poddany cesarza Franciszka Józefa I, niepiśmienny Hucuł Piotr Niewiadomski, zrekrutowany do wojska wraz z innymi krajanami. Jednak w narracji stworzonej przez polskiego prozaika człowiek ograniczony zostaje do kategorii ciała. Ironiczna opowieść obnaża mechanizmy poboru do wojska i hipokryzję Europy w stosunku do swojego „ludu”. W powieści czytamy: „W owych dniach ciała mężczyzn ważono i mierzono. Sortowano je podług gatunków, przebierano, jak kartofle, jak owoce strząśnięte z drzewa żywota. (...) Do tej pory byliśmy tylko nazwiskami (...) chodziły po świecie nazwiska, tuczyły się, rozmnażały, aby w dzień mobilizacji przemienić się w ciała” (Wittlin 1991, 60). Akcja Soli ziemi kończy się na przybyciu rekrutów do garnizonu, czytelnik nie towarzyszy Niewiadomskiemu na polu walki. Postaci Marsa i Eskulapa, przywołane w pierwszym cytacie, odnoszą się bezpośrednio to sytuacji poboru, w której lekarz decydował o losie człowieka, jego zdolności do walki, możliwościach przysłużenia się cesarzowi. Narrator pokazuje również paradoks, który polega na zmianie postrzegania ludzkich ułomności w obliczu wojny:

Do tej pory zdrowie uważano powszechnie za skarb, którym należy się cieszyć i o który należy dbać. Instynkt zdrowia był człowiekowi przyrodzony, choroba natomiast powszechnie uchodziła za zło. Dziś z winy sojuszu Marsa z Eskulapem nastąpiło całkowite odwrócenie wartości. To, co przed 28 lipca było złe, na przykład obustronny katar szczytów płucnych, wada serca, chroniczny katar kiszek, przepuklina, stało się po 28 lipca nie tylko źródłem radości, ale czymś w rodzaju żelaznego 
kapitału, zabezpieczającego od śmierci. Okazało się, że istnieją dwa rodzaje zejścia ze świata: śmierć cywilna, jako skutek cierpień i dolegliwości, że się tak wyrazimy - domowych, oraz śmierć wojskowa, gwałtowna, nawiedzająca organizmy, obdarzone doskonałym zdrowiem (Wittlin 1991, 68).

W podobnym tonie wypowiadał się fizjolog berliński Georg Friedrich Nicolai w Biologii wojny (1919):

Wojna oszczędza niewidomych, głuchoniemych, idiotów, garbatych, chorych na skrofuły, szaleńców, impotentów, paralityków, epileptyków, karłów i wcześniaków. Cały ten odpad ludzkiej rasy może być spokojny, przeciwko nim nie gwiżdżą kule, i podczas gdy młodzi, odważni, silni mężczyźni giną na polu walki, może on spokojnie siedzieć w domu i leczyć swe wrzody (...). Wojna daje im niemal gwarancję życia, gdyż ta cielesna i duchowa „ułomność”, która nie może wytrzymać konkurencji w czasie pokoju wobec jej zdrowych sąsiadów, otrzymuje stałe miejsca i jest wysoko opłacana (Michalik 1994, 385).

Władza, jaką zdobywają lekarze, rodzi pytania natury etycznej i moralnej. W powieści Wittlina można wykupić się od wojska łapówką daną medykowi. Ten, dbając o zachowanie równowagi na szali, skrupulatnie oddaje wojsku ciała niepiśmienne i ubogie, tak by ostateczny rachunek się zgadzał. Nicolai należał do nielicznych lekarzy, którzy otwarcie przeciwstawiali się wojnie. Nowe sposoby walki, w tym zastosowanie gazu bojowego, nie wzbudziły dylematów etycznych u większości przedstawicieli medycyny. Protest berlińskiego lekarza nie przyniósł żadnych rezultatów, a jego społeczne konsekwencje zmusiły go do emigracji. Mars z Eskulapem podczas wojny stoją obok siebie na froncie i w szpitalach garnizonowych. Przed wojną „w szpitalach, w klinikach, w wytwornych sanatoriach leżały w uśpieniu ciała, popsute cywilnymi chorobami" (Wittlin 1991, 14). Podczas trwania walk ciało najczęściej zostaje zranione, ale już nie w wyniku walki na bagnety czy noże, lecz w następstwie ostrzału artyleryjskiego, odłamków granatów, ognia piechoty. Eskulap odnosi zwycięstwo, gdy ratuje ciężko ranionych żołnierzy. Jednak na ich ciałach zostawia ślad okrutny Mars. „Na liście rannych byli więc żołnierze bez nogi, ramion, z urazami psychicznymi, niewidomi, pozbawieni obu nóg, obu rąk, z uszkodzonym kręgosłupem, o zniekształconych twarzach, i to nieraz do tego stopnia, że nie mieli odwagi powrócić do domów, rodzin i miejscowości, z których pochodzili" (Chwalba 2014, 429). Podsumowanie polskiego historyka można zestawić z fragmentem eseju Wittlina Wojna, pokój i dusza poety z 1925 roku:

Od owych upalnych i niepojętych dni, obok miliardów ludzkich słów i opinii, drukowanych w zapomnianych gazetach, dzieli nas dzisiaj piramida niezapomnianych ludzkich czynów, oraz góry kilkudziesięciu milionów trupów, dzielą nas lasy odrąbanych nóg i rąk, i morza przelanej krwi. Jeszcze nas straszą żywe upiory bez nosów, bez uszu, jeszcze kuśtykają po brukach miast nieszczęśliwi sprzedawcy gazet, jeszcze nie wymarli wszyscy inwalidzi (Wittlin 1991, 24-5).

Obraz okaleczonych żołnierzy wracających do domu stanie się nieodłącznym elementem nowoczesnej wojny, wykorzystywanym również w literaturze 
najnowszej (można choćby wspomnieć o powieści Szczepana Twardocha Morfina). W eseju Wittlina powieściowe „ciało” zamienione zostaje w „trupa”. Tym zabiegiem autor obnaża mechanizmy manipulacji językowej, które stają się nieodłącznym elementem relacjonowania konfliktów zbrojnych. Semantyczne przesunięcia relacji trup - ciało francuski antropolog wyjaśnia tak:

słowo «trup» przejmuje dreszczem. Jednakże akceptuje się je na oznaczenie zmarłych dalekich lub anonimowych, to znaczy wtedy gdy śmierć jest wystarczająco odległa w czasie i przestrzeni z jednej strony, a w polu uczuciowym - z drugiej. Na przykład mówić się będzie o trupach żołnierzy poległych na wojnie, ale ich ciała sprowadzi się dla rodziny (Thomas 1991, 307).

W powieści Wittlina mężczyźni powołani do wojska stają się anonimową masą. Użycie słowa „ciało” nabiera charakteru ironicznego, pokazuje uprzedmiotowienie jednostki przez władzę. Z perspektywy „machiny wojennej” Piotr Niewiadomski staje się jednym z wielu żołnierzy, nie ma znaczenia jego narodowość, poglądy czy cechy indywidualne. Sceny poboru pokazują, że aspekty fizyczne i zdrowotne również przestają mieć znaczenie w sytuacji nieuczciwości lekarzy. Totalność wojny przejawia się w liczbach. Ważna jest wielkość poszczególnych oddziałów, przewaga ilościowa na polu walki. Słowo „trup” użyte w eseju Wojna, pokój i dusza poety oddaje charakter konfliktu zbrojnego, w którym nie ma bohaterów. Coraz częściej nie ma też ciała, które mogłoby zostać pochowane przez rodzinę. Pozostają zbiorowe mogiły i anonimowe pomniki.

Zawiłe relacje między wojną a medycyną można prześledzić w wielu tekstach stawiających sobie za cel diagnozę nowoczesności. Enzo Traverso konstatuje:

ergonomiści, higieniści, i psycholodzy pracy znaleźli w armii doskonały grunt do weryfikacji swoich hipotez dotyczących dyscypliny ciał, organizacji przestrzeni i psychotechnik. Specjaliści od kwestii zmęczenia wywołanego pracą przemysłową (neurastenii, katapleksji itp.) mieli okazję zajmować się wyczerpanymi życiem w okopach żołnierzami lub dochodzących do siebie po bombardowaniach, stanowiących wdzięczne obiekty terapii eksperymentalnych. Słownik medycyny i psychiatrii wzbogacił się o nowe słowa, popularyzując zarazem szereg wrażeń, takich jak szok traumatyczny, histeria wojenna itd. Inżynierowie i psychotechnicy opracowali sposoby przystosowania kalek wojennych do pracy przy produkcji przemysłowej (Traverso 2011, 109).

Człowiek w obliczu wojny zamienia się w ciało zarówno w oczach lekarzy, którzy decydują o skierowaniu na front, jak i w szerszej perspektywie olbrzymiej machiny wojennej. Lista poddanych, przemielona przez biurokratyczne sito, przeobraża się w oddziały ciał, które należy ogolić, zdezynfekować i jednolicie ubrać. Zdrowie i siła stają się cechami niepożądanymi, ponieważ potencjalnie skazują na śmierć. Najmniejsze oznaki choroby mogą oznaczać ocalenie. Wojna zmienia ciało, wpływa zarówno na kondycję fizyczną, jak i psychiczną człowieka. 


\section{Żołnierz nieznany}

Nieznany jest człowiek, który w tej wojnie pierwszy dał życie.

Nieznany jest człowiek, który go zabił.

Nieznany jest ostatni człowiek, który poległ w tej wojnie.

Moje słowo dobywa go z ziemi, w której leży: on mi przebaczy tę ekshumację.

Nieznany jest Żołnierz Nieznany

(Wittlin 1991, 28).

Pomniki Żołnierza Nieznanego zaczynają pojawiać się w Europie po I wojnie światowej, pierwszy z nich powstał w Paryżu w 1920 roku. Mają one podtrzymywać pamięć o bezimiennym człowieku, który oddał swoje życie w obronie ojczyzny. Zastępują pomniki bohaterów, którzy wsławili swoje imię w boju. Traverso tak opisuje tę zmianę:

Przystąpienie do wojny zadeklarowała w sierpniu 1914 r. większość europejskich stolic, upatrując w niej okazję do potwierdzenia wartości nacjonalistycznego ethosu: męskości, siły, odwagi, heroizmu, świętej unii. Stary świat pogrążył się $\mathrm{w}$ falach przemocy i oczyszczającego bitewnego ognia. Patriotyczne upojenie szybko zastąpiło odkrycie nowoczesnego horroru - anonimowej masowej śmierci, uprzemysłowionej masakry, zbombardowanych miast i spustoszonych pejzaży. „Pola chwały” zyskały zupełnie nowe oblicze - rozciąganych na setki kilometrów okopów, w których żołnierze spędzali całe miesiące wśród błota i drutu kolczastego, a nierzadko też w towarzystwie szczurów i zwłok swoich towarzyszy (Traverso 2011, 107).

Wojna okopowa niesie ze sobą wiele zmian w obrazie żołnierza. Dumną postawę wyprostowaną zastępuje poza skulona (Audoin-Rouzeau 2014). Wojsko ma się stać niewidoczne. Barwne mundury zostają odłożone na pokojowe defilady. Długotrwałość działań wojennych, wielogodzinne marsze sprawiają, że ciało zrasta się z mundurem - metaforycznie i dosłownie:

Brud, niemożność umycia się, odór rozkładających się zwłok, zadrapania, rany, odciski, wszystko to sprawia, że śmierć staje się czymś „banalnym”, traci „epicki” charakter „śmierci na polu chwały” na rzecz typowo nowoczesnej - anonimowej śmierci $\mathrm{w}$ masie. Bohaterem $\mathrm{w}$ tej wojnie nie był już żołnierz, który dzięki swej odwadze, zaletom i cnocie wydobywał się z anonimowości, zapisując swe imię złotymi zgłoskami na Olimpie heroizmu, ale właśnie „Nieznany Żołnierz” (Traverso 2011, 114).

Ciała mają narodowość, ale służy ona wyłącznie zlokalizowaniu ich po jednej ze stron konfliktu. Wśród liczb i rachunków wymienia się żołnierzy zaangażowanych w wojnę przez konkretne państwa, sumuje się je w myśl zawartych sojuszy. Tych samych operacji dokonuje się na ciałach rannych i zabitych. Pozostają jeszcze cywile, których nie oszczędzają epidemie i głód. Ponadto po stronie „ciał zabitych" widnieją straty bojowe i niebojowe. A do ogólnych kosztów i zniszczeń wojennych należy również doliczyć broń, wszelkie dobra materialne, ekonomiczne obciążenia, spalone wioski, uszkodzone tory kolejowe itp. 
Nie bez znaczenia pozostaje rubryka zysków. Ludzkość po Wielkiej Wojnie otrzymuje zdobycze techniki oraz medycyny. Geograficzne i polityczne przeobrażenia w Europie pociągają za sobą ogromne zmiany, szczególnie z perspektywy poszczególnych narodów i państw. Osiągnięcia nauki mają jednak charakter totalny, przekraczają dawne linie frontów. Po zawarciu pokoju odkrycia medycyny stają się dobrem wspólnym.

Ciało w obliczu wojny 1914-1918 po raz pierwszy w historii europejskich pól bitewnych staje się anonimowe na masową skalę. Ocaleni, ale i doświadczeni wojną żołnierze, wracają do swoich rodzin. W społecznym krajobrazie coraz więcej jest ciał kalekich, nierzadko niezdolnych do samodzielnego egzystowania. Pojawia się problem zapewnienia odpowiedniej opieki i środków do życia dla weteranów. Niepełnosprawni będą jedną z głównych sił pacyfistycznych, sprzeciwiających się kolejnym konfliktom.

Związek między wojną a przemysłem wydaje się dziś oczywisty. W diagnozie nowoczesności pojawiają się hasła związane z industrializacją. Rozwój przemysłu wpływa na sposób rozwiązywania i prowadzenia działań zbrojnych. Podobieństwa widoczne są w organizacji wojska, masowości przedsięwzięć, a także w postrzeganiu jednostki. Żołnierz i robotnik tracą swoją tożsamość i historię na rzecz anonimowego tłumu.

\section{Laboratorium przemocy}

I wojna światowa to też rozprzestrzeniające się zarazy, wynikające z braku higieny i osłabienia organizmu. Pandemia grypy, która rozpoczęła się pod koniec Wielkiej Wojny, pochłonęła więcej ofiar niż sam konflikt militarny. Zakres czasowy, przemieszczanie się wojsk, które przyczyniło się do rozprzestrzeniania zarazy, oraz ogólny bilans strat wojennych i zgonów spowodowanych chorobą sprawia, że oba wydarzenia stają się komplementarne. Zmagania z chorobami zakaźnymi, w szczególności z durem brzusznym, opisuje w swoich wspomnieniach Ludwik Hirszfeld. Na tyłach wojska laboratorium zamienia się w poligon doświadczalny dla rozwoju szczepionek i badań nad grupą krwi. W Historii jednego życia autor wspomina również II wojnę światową, podczas której osiągnięcia medycyny stają się narzędziem propagandy w rękach oprawców (Hirszfeld 2000).

Nie bez powodu tworzymy analogie pomiędzy konfliktami militarnymi. Enzo Traverso (2011) pokazuje ewolucję przemysłowo-militarną, która doprowadziła do nazistowskiej przemocy. Sposób prowadzenia przez autora narracji powoduje, że podobieństwo między I a II wojną światową nasuwa się automatycznie. Sven Lindqvist (2009) sięga do krwawej historii kolonializmu, by pokazać drogę Europy do Zagłady. Wytępić całe to bydło to rozważania na temat źródeł europejskiego „jądra ciemności”. Kontekst ekonomiczny oraz próba charakterystyki tworzących się systemów totalnych, maszynerii zagłady, pozostają wspólne dla badaczy zbrodni minionego wieku. Masakry, ludobójstwa, eksperymenty - wszystkie te strategie 
postępowania z ciałem mają swoje źródła w przeszłości i rzutują na kolejne konflikty militarne.

Jak można wnioskować z analizy sytuacji żołnierzy w trakcie I wojny światowej, wojna jest przede wszystkim doświadczeniem ciała: „Na wojnie to ciała dopuszczają się przemocy, to ciała jej doświadczają. Ta cielesność wojny tak ściśle łączy się z samym zjawiskiem wojennym, że nie jest łatwo oddzielić "historię wojny” od pewnej antropologii historycznej doświadczeń cielesnych spowodowanych przez działania wojenne" (Audoin-Rouzeau 2006, 263).

Wielka Wojna, przez swoją skalę, dotknęła ciał w sposób szczególny. Jej długotrwałość i wyniszczające metody walki spowodowały ogromne straty. Szacuje się, że liczba rannych wyniosła ponad 20 milionów (Madajczyk 1987). Postęp i możliwości ówczesnej medycyny niewątpliwie przyczyniły się do zwiększenia tempa powrotu rekonwalescentów na pole walki, a rozwój systemów szpitali polowych (np. ambulanse Curie) dał wielu żołnierzom możliwość przeżycia. Z drugiej jednak strony, rozwój techniki wojennej (użycie gazu bojowego i miotaczy płomieni, bombardowania) znacząco wpłynął na ostateczny bilans wojny.

Ciało zranione na wojnie staje się zdeformowane i odrażające. Medycyna nie posiada jeszcze możliwości rekonstrukcji. Dopiero rozwija się chirurgia i ortopedia, powstają coraz doskonalsze protezy. Niepełnosprawność i kalectwo czynią niemalże powszechnym obraz ciała doświadczonego wojną. Pole walki zamienia się w laboratorium nowoczesności, umożliwia równoczesne ratowanie życia i skazywanie ciała na cierpienie. Wojna przyczyniła się do rozwoju nauki (w tym medycyny), ale równocześnie przyniosła nowe dylematy etyczne i moralne. Zadbane ciało mieszczańskie staje się ciałem kalekim, zmuszającym do przedefiniowania obrazu ciała w epoce.

Nieustanny postęp, umożliwiający przedłużanie ludzkiego życia, walkę ze „śmiertelnymi chorobami”, zwalczanie chorób uznawanych wcześniej za nieuleczalne, przyczynia się również do przetrwania koncepcji „podłych ciał”, „życia niewartego życia”, kształtowania lepszego człowieka (zob. Chamayou 2012). Wojna dostarcza wiedzy o ludzkiej anatomii i wytrzymałości. Rany doznane przez żołnierzy są rozległe (doskonale pokazują budowę tkanek i narządów wewnętrznych) i zmuszają do podejmowania ryzykownych zabiegów. Doświadczenie lekarzy wojskowych staje się niezwykle cenne w konstruowaniu nowych hipotez, weryfikowaniu teorii, które w wyniku braku materiału do badań nie mogły zostać wcześniej sprawdzone. Nauka, która przynosi ludzkości oręż do walki przeciwko wirusom i bakteriom, stwarza równocześnie śmiertelne środki chemiczne. Dwa wielkie zagadnienia nowoczesności (postęp medycyny i techniki), w kontekście tematyki cielesności, wydają się oczywiste i jednocześnie bardzo trudne do syntetycznego ujęcia. Kulturowa teoria literatury pozwala zapytać nie tylko o kondycję człowieka w nowoczesności ujętą w dziele literackim, ale inspiruje również do refleksji nad zagadnieniami, które wymagają wiedzy z innych obszarów: 
historii, antropologii czy ekonomii. Lekturę Soli ziemi można wzbogacić o kolejne kwestie: czy Eskulap może poradzić sobie bez Marsa? Czy wojna totalna byłaby możliwa bez rozwoju przemysłowego? Wittlin ani nie daje odpowiedzi na te pytania, ani nie zajmuje się analizą historyczną wyjaśniającą przyczyny konfliktu, jednak literacka refleksja nad XX wiekiem wydaje się niezbędna w humanistycznym dyskursie o nowoczesności.

\section{Bibliografia:}

Audoin-Rouzeau Stéphane, 2014, Masakry. Ciało i wojna, w: Courtine J.-F. (red.), Historia ciała. Różne spojrzenia. Wiek XX, Belaid K., Stróżyński T. (przeł.),

Gdańsk, s. 263-297.

Chamayou Grégoire, 2012, Podłe ciała. Eksperymenty na ludziach w XVIII i XIX wieku, Bodzińska J., Thiel-Jańczuk K. (przeł.), Gdańsk.

Chwalba Andrzej, 2014, Samobójstwo Europy. Wielka Wojna 1914-1918, Kraków.

Foucault Michael, 1977, Archeologia wiedzy, Siemek A. (przeł.), Warszawa.

Foucault Michael, 2002, Porzadek dyskursu. Wykład inauguracyjny wygłoszony w Collège de France 2 grudnia 1970, Kozłowski M. (przeł.), Gdańsk.

Hirszfeld Ludwik, 2000, Historia jednego życia, Warszawa.

Lindqvist Sven, 2009, Wytępić całe to bydło, Haykowska M. (przeł.), Warszawa. Madajczyk Czesław, 1987, I i II wojna światowa. Analogie i różnice, Warszawa.

Michalik Marian B. (red.), 1994, Kronika medycyny, Warszawa.

Przymuszała Beata, 2015, Wobec cielesnej ekspansji - poetyckie reakcje, „Polonistyka. Innowacje”, nr 1, s. 16-26.

Thomas Louis-Vincent, 1991, Trup, Kocjan K. (przeł.), Łódź.

Traverso Enzo, 2011, Europejskie korzenie przemocy nazistowskiej, Czarnacka A. (przeł.), Warszawa.

Trubicka Hanna, 2011, Problem kryzysu humanizmu w „Soli ziemi” Józefa Wittlina, „Zagadnienia Rodzajów Literackich”, z. 2, s. 209-228.

Wantuch Wiesława, 2015, Wojenna rozsypanka, „Polonistyka. Innowacje”, nr 1, s. 80-90.

Wittlin Józef, 1991, Sól ziemi, Wiegandt E. (oprac.), Wrocław.

Wittlin Józef, 1991, Pisma pośmiertne i inne eseje, Warszawa.

\section{O Autorce:}

Beata Koper - doktorantka na Wydziale Filologii Polskiej i Klasycznej UAM, dokumentalistka w Instytucie Badań Literackich PAN. Jej zainteresowania badawcze oscylują wokół dyskursów medykalizujących w nauce i sztuce. 
